\title{
Application of Experiential Teaching in the Reform of College Students' Mental Health Course from the Perspective of Life Education
}

\author{
Jiaojiao Li*, Mei Chen \\ Guangzhou Huashang College, Guangzhou 511300, Guangdong Province, China \\ *Corresponding author: Jiaojiao Li, xianq373759@163.com
}

\begin{abstract}
In recent years, the phenomenon of college students' indifference to life occurs frequently which seriously damages the healthy growth of college students. Life education should be integrated into mental health education courses in colleges. Experiential teaching is a type of teaching activity that is characterized by students' personal experiences and initiative, focusing on the participation of practical activities. Compared with traditional lectures, it improves students' interest and enthusiasm. In the mental health course, experiential teaching applies theoretical knowledge to real life and promote the improvement of students' mental health to shape stable and mature personalities and eventually, promotes the development of life. College students' mental health course should be integrated with experiential teaching practice in the perspective of life education, so as to better improve the teaching effect and guide students to form a correct outlook of life.
\end{abstract}

Keywords: Life education; Experiential teaching; Reform of college students' mental health course

Publication date: August 2021; Online publication: August 30, 2021

\section{Introduction}

In 2011, the Ministry of Education issued the "Basic Requirements for the Teaching of Mental Health Education among College Students" which emphasized that the current important task of strengthening and improving ideological and political education is to strengthen and improve the mental health education among college students. College students' mental health course is the main way of mental health education propaganda. It is particularly important whether the course brings about teaching effects as well as whether its curriculum can adapt to the changes and development of the times.

University is the stage of transition from school to the society. In the real environment with the increasingly accelerated pace of life, college students are facing many setbacks and challenges. Therefore, more and more psychological issues have arisen, even the phenomenon of being indifferent to their lives. Teenagers are the hope of the country who shoulder the important task of rejuvenating the Chinese nation; hence, life education for college students is necessary. Life education refers to guiding and leading college students to cultivate respect for life, cherish life, develop the potential of life, and constantly explore the value of life ${ }^{[1]}$. The mental health education course in colleges should be constantly integrated with life education in which the setting of their course content should be closely around cherishing life. Therefore, it is worth thinking about the reform of college students' mental health course from the perspective of life education.

With the continuous development of the society, the psychological needs of students are changing. The mental health curriculum in colleges no longer simply solves the problems of students' psychological barriers but some developmental problems in regard to the growth of college students have gradually 
attracted attention. The mental health curriculum which solely relies on the dissemination of knowledge cannot solve these puzzles. Therefore, in order to ensure the effectiveness of its curriculum, there is a need to continue to explore curriculum reform ideas. Among them, experiential teaching has attracted the attention of researchers. American social psychologist, David Cooper proposed experiential teaching ${ }^{[2]}$ where learning is not the results but more attention should be paid to its process. This process is based on experience including situational experience, case teaching, and role-playing. Strictly speaking, experiential teaching implies that under the guidance of teachers, the priority is the students' learning, and its core is to solve practical problems and promote students' use of knowledge ${ }^{[3]}$. In college students' mental health course, experiential teaching mainly includes students' active participation, introspection, and exploration of themselves with practical activities as the carrier in order to guide students to deal with emotions, cognitions, and other psychological confusions in achieving the effect of relieving psychological distress ${ }^{[4]}$. Research has confirmed that experiential teaching can improve the teaching effect of college students' mental health course, but it is rarely discussed from the perspective of life. The innovation of this article is to explore the ideas and methods of integrating experiential teaching into college students' mental health course from the perspective of life education in order to provide some theoretical reference value for the reform of college students' mental health course.

\section{Current situation of integrating mental health course with life education for college students}

According to the contents of college students' mental health education textbooks, the current situation of life education shows as follows:

First, life education is rarely regarded as a single chapter in textbooks. The content of the course mainly includes introduction, self-awareness, interpersonal relationship, love and sex, learning psychology, emotion management, stress and dealing with setbacks, as well as crisis intervention. Two chapters are in relation to the meaning of life which are self-awareness and crisis intervention. These involve selfawareness, acceptance and improvement, as well as prevention of suicide and other crisis. These two chapters mainly compose of self-discussions and how to prevent the occurrence of suicide events but not from the perspective of life education to guide students. Education about the value of life and other contents are not included in which students may learn on how to improve themselves but it may be difficult to understand how to cherish life, whether it is their own or others' in understanding the awe of life and nature.

Second, the course equates life education with the prevention of suicide and other crisis. The mental health work in colleges is not only to prevent the occurrence of these events but also to pay attention to the mental health status of their students, guide them to improve their psychological quality, find their own value, cherish life, and eventually love the society and the country. Life education is not equal to suicide prevention education, but it concerns the development of students so that they can learn to understand the value of life.

Third, due to limited teaching resources and conditions, the form of teaching is basically large classes with large number of students. Hence, it is difficult to conduct teaching through experiential activities. At the same time, the incentive mechanism adopted by teachers is also single. College students themselves do not pay enough attention to the mental health education course. If there is no attendance system, students' participation may be lower. From the inner point of view, students lack interest and motivation in learning; hence, the teaching effect is relatively poor, and it is difficult for students to really learn and use the knowledge resulting in a lack of coping skills when facing problems.

Fourth, mental health courses in many colleges are public compulsory courses or elective courses where students have less time to communicate with their teachers and the evaluation method is basically through examination which results in students just trying to cope with the examination rather than mastering relevant knowledge. Students pay more attention to the understanding of theoretical knowledge, and they lack training opportunities to integrate theory into practice. In addition, students encounter practical psychological problems and lack practical coping skills which lead to the inability of these mental health 
classes to display their value and students would find it difficult to understand. Even after these courses, many students hardly receive practical thinking and inspiration. It is a pity that one is unable to use what they have learned to solve actual psychological confusion.

\section{Necessity of integrating the idea of life education into college students' mental health course}

College students are the main force of the continuous development and construction of the motherland. If the youth is strong, the country will be strong in which their life education is particularly important. In the process of imparting mental health knowledge, college students' mental health curriculum should integrate the concept of life education. Students need to be guided to establish correct outlooks on life and values as well as to respect life and realize the value of life.

First, college students are the inevitable requirement for the future development of the country. The youth is the hope and future of the national development. China has always attached great importance to education and the development of their students in training the successors of communism. In view of that, the education of college students' outlook on values and life is particularly important. At present, college students are faced with many opportunities and challenges. There are many negative influences from the internet which impact the formation of correct values. The phenomenon of internet addiction, campus loans, psychological crisis, and so on among college students have a serious impact on the mental health of today's college students. Students' extreme events are constantly emerging which reflect their indifference to life and the society as well as their lack of correct outlook on life and sense of social responsibility. Under this premise, the mental health curriculum for college students should be integrated with life education and to be constantly improved.

Second, the premise of college students' physiological and social adaptation to an all-rounded development is to establish a correct outlook on life. The idea of life education should be a guiding ideology in college students' mental health curriculum. Life education is a necessary approach to promote the development of college students' physical and mental health ${ }^{[5]}$. In recent years, with the rapid development of the market economy, information explosion, and unhealthy social environment, the physical and psychological pressures among teenagers have been increasing. Parents' educational concepts have changed, and they have been more demanding on their children. There is almost no life education in schools. As a result, there are some events that have shown that students do not cherish life such as self-mutilation, suicide, wounding, killing, and so on. It is a pity to the country and family when college students do not pay attention to their lives; hence, it is difficult to form correct outlooks on life and in shouldering the responsibility of developing the motherland. It can be seen that mental health education needs to be reformed from the perspective of life education so as to cultivate comprehensive and harmonious successors for socialist construction.

\section{Exploring experiential teaching in the reform of mental health course from the perspective of life education}

Research has proved that the application of experiential teaching in college students' mental health course is feasible and necessary ${ }^{[6]}$. Silver Star research found that experiential teaching is more effective than lectures in terms of students' satisfaction and learning ${ }^{[7]}$. Qiu Xiaoyan and others have found that experiential teaching has obvious effect in strengthening college students' psychological quality and improving their mental health ${ }^{[8]}$. It can be seen that experiential teaching can promote college students' mental health curriculum to better realize the teaching objectives. In view of life education, it is worth exploring on how to integrate experiential teaching in the reform of college students' mental health curriculum. 


\subsection{Strengthening the faculty construction of college students' mental health course}

The role of teachers in college students' mental health course is very important. A good faculty is an important guarantee to carry out experiential teaching. Teachers should start to understand the connotation and implementation of experiential teaching in which they should focus on the integration of situational experience method, case teaching, and role-playing, then, applying them into practical teaching. Moreover, teachers should carefully select teaching contents and organize its application. In addition to imparting theoretical knowledge, they should also strengthen the practical experience in classes. Teachers should pay attention to shape their own personality as their morality is very important. Teachers should be examples for students in respecting and cherishing life. Only in this way students can appreciate their teachers' morality and gain more knowledge in the actual teaching. Therefore, colleges should strengthen the training of professional teams to build high-quality professional teams, actively devote themselves to teaching research and reform, and then optimize the teaching effect of the mental health course for college students. For both full-time and part-time teachers, there is a need to focus on training and polishing, encouraging them to carry out collective lesson preparations, brainstorm, exchange experiences, discuss teaching contents, and designs, as well as actively apply for scientific research projects in building a high-quality teaching team. Teachers should also adhere to the concept of life education, integrate life education in their teaching contents, as well as set teaching objectives and contents with this goal.

\subsection{Strengthening the construction of practice teaching facilities for college students' mental health course}

Classroom is the basic way to conduct mental health education for college students. Traditional lectures which are carried out in classrooms have certain limitations in the practice of experiential teaching. In developing existing facilities, the role-playing method and case discussion method can be added so that students would be able to join in the teaching content and they would become the focus of the teaching. In practice teaching, theoretical knowledge should be applied into practice and students' practical problems should be solved. For example, real situations can be set up in class so that students can solve practical problems through role-playing. In addition, brainstorming can also be closer to students' practical problems in order to easily arouse students' resonance and thinking. With the development of the society and the continuous improvement of living standards, traditional teaching courses cannot meet the needs of students; hence, practice teaching should be integrated into traditional teaching courses. Colleges should strengthen the construction of practice teaching facilities and set up teaching venues such as psychological scene experience room, movie therapy center, psychological theater, sand table game room, and painting psychology center in order to provide rich practice teaching conditions and facilities for experiential teaching. At the same time, the implementation of experiential practice teaching requires vigorous promotion and supervision from various departments as well as the active participation of the students.

\subsection{Enriching the content of college students' mental health course}

College students' psychological issues are not simply individual problems. From a broader perspective, they involve life philosophies. It can be considered that the conflict of an individual's outlook on life and values leads to inner contradiction and pain. It is not enough to discuss the knowledge of self-consciousness, interpersonal relationship, learning, and emotion to solve the fundamental problems faced by students. Therefore, the contents of college students' mental health curriculum should be integrated with the teaching contents of life education in order to guide students to form a correct outlook on life based on themselves and then promote a comprehensive, healthy, and harmonious development. Moreover, colleges should decide on the curriculum objectives and contents based on students' life education to allow students to think 
about their own values, develop life wisdom and potential, guiding them to respect and cherish life, as well as to solve their own practical psychological puzzles in experiential practice teaching. At the same time, group psychological counseling, psychological quality development activities, and other experiential teaching mode should be integrated into life education. These allow students to participate in their classrooms, truly follow their hearts, feel the psychological changes in actual experiences, and inspire the thinking about themselves and their life ${ }^{[9]}$.

\subsection{Transforming the evaluation system}

In view of the traditional teaching, the evaluation in college students' mental health courses is through final examinations. It is difficult to reflect the students' usual learning effect through this kind of examination. Therefore, the evaluation system needs to be changed where students' learning effect should be evaluated from multiple angles and in an all-rounded way. The evaluation of college students' mental health courses includes classroom theoretical knowledge examination and experiential teaching practice examination. In experiential teaching practice, teachers can record or observe each activity that has been conducted to form a certain evaluation standard according to that activity. Students on the other hand, can test their learning effect through the activity and a summary from it. In order to enhance the enthusiasm of students' participation, the final evaluation system should be plentiful. By combining the content evaluation system with the process evaluation system, it can better test the students' learning effectiveness, effectively guide students to learn and practice, as well as effectively promote the realization of teaching objectives.

\subsection{Promoting the realization of small class teaching mode}

Experiential teaching practice is more suitable for small class teachings. If there are too many people, it is difficult to carry out experiential practice activities. Even if they are carried out, they would only aim at certain students. Hence, not every student would benefit from them in addition to the declination of the teaching effect. Colleges should promote small class teaching, strengthen the construction of retired teachers, and ensuring the basic conditions of small class teaching. At the same time, in terms of course credit, credits can be given to promote the realization of small class teaching. Group counseling, roleplaying, situational drills, sand table games, etc. require the control of the number of students so that teachers can better lead the students in participating, guide them in acquiring mental health knowledge, and eventually realizing their psychological growth.

\section{Conclusion}

College students' mental health course shoulders the responsibility of promoting the mental health growth of college students. Colleges should constantly comply with the pace of the times and actively promote the continuous development as well as the improvement of the curriculum. From the perspective of life education, experiential teaching practice which uses situations and activities for teaching has flexible forms. This allows students to really participate in classrooms, brightens the classroom atmosphere, improves the enthusiasm of students, and changes the previous teaching mode. In addition, it allows students to acquire mental health knowledge through experiential activities, learn methods to solve psychological puzzles, establish a good relationship with their classmates, realize the growth of the soul, and enrich the content of life which is of great significance.

In general, the college students' mental health course should integrate experiential teaching into its curriculum from the perspective of life education. It guides students to use what they have learned and better understand the value of life to realize the all-rounded development of college students, promote the realization of mental health curriculum goals, as well as realize the value of mental health education. 


\section{Disclosure statement}

The authors declare that there is no conflict of interest.

\section{References}

[1] Chu H, 2015, Theory and Practice of Life Education for College Students, Nanjing Normal University Press, Nanjing.

[2] Cooper D, 2008, Experiential Learning - Making Experience the Source of Learning and Development [Wang C, et al., Trans.], Shanghai East China Normal University Press.

[3] Wang X, Liu Y, Liang Y, et al., 2017, Reform and Practice of "Student-Centered" Teaching, Learning and Examination Method. China University Teaching, (6): 73-6.

[4] Xue C, 2020, Exploration of Experiential Practice Teaching in College Students' Mental Health Education Course. School Party Construction and Ideological Education, (9): 72-9.

[5] Chang S, Li M, 2017, Life is Like Summer Flowers: An Introduction to College Students' Life Education". Tsinghua University Press.

[6] Gao F, 2013, On Experiential Teaching in College Mental Health Education. Journal of Southwest Jiaotong University, (2).

[7] Yin X, 2010, Empirical Research on the Effectiveness of Experiential Teaching in College Psychology. Education and Occupation, (14).

[8] Qiu X, Song H, 2013, Experimental Research on Experiential Teaching of College Students' Mental Health Education. Journal of Educational Science of Hunan Normal University, (1).

[9] Sun G, Xue C, 2020, Mental Health Education of College Students from the Perspective of Life Education. Party Construction and Ideological Education in Schools, 11: 71-2. 